\title{
ESTIMATES OF GENETIC GAINS FOR GROWTH TRAITS IN YOUNG PLANTS OF Eucalyptus urophylla S. T. Blake
}

\author{
Thais Galhardo Godoy ${ }^{1}$, Sebastião Carlos da Silva Rosado²
}

(received: March 10, 2010; accepted: February 25, 2011)

\begin{abstract}
The objective of this study was the selection of superior genotypes for growth traits, correlating them to initial height growth in the field, at age eight months. A random block design was used in the nursery, with eight clones, three replicates and four plants per plot. And a random block design was also used in the field, with eight clones, four replicate blocks and nine plants per plot. Data being analyzed in the nursery at age 120 days included: height of field seedling, at age eight months (Hc), height of nursery seedling $(\mathrm{Hm})$, root collar diameter (Dc), shoot diameter (Db), shoot dry matter (PMSPA), root dry matter (PMSR), total dry matter (PMST), ratio of shoot dry matter to root dry matter (PMSPA/PMSR), Dickson quality index of root collar diameter (IQD-Dc), Dickson quality index of shoot diameter (IQD-Db). Analyses of variance showed that significant genetic differences exist among clones for all traits and, given the high heritability values found, the estimated genetic gains were generically very high. As for predicted indirect genetic gain, selection in nursery seedlings for Dc, PMSPA/PMSR, IQD-Dc provided the highest values of indirect gain in field seedling height.
\end{abstract}

Key words: Initial growth of seedlings, genetics, forest improvement.

\section{ESTIMATIVAS DE GANHOS GENÉTICOS EM CARACTERES DE CRESCIMENTO EM PLANTAS JOVENS DE Eucalyptus urophylla S. T. Blake}

\begin{abstract}
RESUMO: Objetivou-se, com este estudo, selecionar genótipos superiores para características de crescimento, correlacionando-as com o crescimento inicial em altura no campo, aos oito meses de idade. O delineamento usado no viveiro foi o de blocos casualizados, com oito clones, três repetições e quatro plantas por parcela. O delineamento utilizado no campo também foi de blocos casualizados, com oito clones, quatro blocos e nove plantas por parcela. Os dados avaliados no viveiro aos 120 dias de idade foram: altura das mudas no campo, após oito meses de idade (Hc); altura da muda (Hm); diâmetro do colo da muda (Dc); diâmetro do broto da estaca (Db); peso de matéria seca da parte aérea (PMSPA); peso de matéria seca da raiz (PMSR); peso de matéria seca total (PMST); relação entre peso de matéria seca da parte aérea e peso de matéria seca de raiz (PMSPA/PMSR); índice de qualidade de Dickson do diâmetro do colo (IQD-Dc); índice de qualidade de Dickson do diâmetro do broto (IQD-Db). As análises de variância mostraram que existem diferenças genéticas significativas entre clones para todos caracteres e, tendo em vista os altos valores de herdabilidade encontrados, os ganhos genéticos estimados foram de grande magnitude. No estudo de previsão de ganho genético indireto, verificou-se que a seleção, em mudas no viveiro, para Dc, PMSPA/PMSR, IQD-Dc propiciou os maiores valores de ganho indireto em altura das mudas no campo.
\end{abstract}

Palavras-chave: Crescimento inicial de mudas, genética, melhoramento florestal.

\section{INTRODUCTION}

Species of genus Eucalyptus play an important economic, social and environmental role for Brazil. Up until 2007, the estimated area reforested with Eucalyptus was 3,771,867 ha (ABRAF, 2008), expected to produce enough timber to supply mainly the Brazilian industrial sector, in particularly cellulose pulp production and charcoal-fuelled steel metallurgy.

The successful use of Eucalyptus species is largely due to the following aspects: i) dozens of species are easily adaptable and grow rapidly under various Brazilian ecological conditions, ii) these species are the most commonly used in large-scale production of short-fiber pulp and wood charcoal, iii) they have the best potential for use in large-scale clonal silviculture, helping obtain a more homogeneous raw material, in amounts and with the quality to best suit each specific industrial use, iv) the considerable inter- and intra-specific variability of genus Eucalyptus, expressed by its diversified wood properties, allows its use in a wide range of technological processes.

Given the expansion of reforested areas in Brazil and the increasing demand for timber by the Brazilian forest-based industry, more and more forest planting is expected to be carried out in all seasons of the year.

${ }^{1}$ Forest Engineer - Departamento de Ciências Florestais - Universidade Federal de Lavras - Cx. P. 3037 - $37200-000$ - Lavras, MG, Brasil thais_galhardo@yahoo.com.br

${ }^{2}$ Forest Engineer, Professor PhD in Forest Improvement - Departamento de Ciências Florestais - Universidade Federal de Lavras - Cx. P. 3037 37200-000 - Lavras, MG, Brasil - scrosado@dcf.ufla.br 
And this will require the use of seedlings with superior physiological quality so as to increase tolerance to environmental stresses, including stress when planting is conducted other than in the rainy season or when unexpected rainfall shortage looms during the rainy season.

One of the major concerns in silviculture is taking healthy, vigorous seedlings to the field, as they will have to survive, develop and grow under biotic and abiotic stress conditions once planted. It is thus crucial to conduct genetic improvement programs seeking selection of material that will, in the nursery stage, present seedlings with quality traits and thus help achieve the desired success in field conditions.

The objective of this work was to select superior genotypes for growth and quality traits of seedlings from clonal E. urophylla, and to evaluate the efficiency of seedling selection in the nursery in relation to their growth response in the field, at age eight months.

\section{MATERIAL AND METHODS}

In this experiment clonal seedlings were used, as produced by the minicutting technique (vegetative propagation in the nursery of Carvovale Ltd.). The forest nursery owned by Carvovale Ltd. is located in the municipality of Taiobeiras, in Vale do Jequitinhonha region, at coordinates $42^{\circ} 14^{\prime} 10^{\prime \prime}$ west longitude and $15^{\circ} 48^{\prime} 30^{\prime \prime}$ south latitude. According to Koppen classification, the predominating local climate is dry, continental, with average annual precipitation less than $1,000 \mathrm{~mm}$ and average maximum temperatures around $34^{\circ} \mathrm{C}$ (COMPANHIA DE PESQUISA DE RECURSOS MINERAIS - CPRM, 2004).

Seedlings were produced in $50 \mathrm{~cm}^{3}$ tubes and kept in plastic trays with 96 cells $80 \mathrm{~cm}$ above ground level. The substrate used was composed of $40 \%$ vermiculite, $30 \%$ scorched rice husk, $10 \%$ coconut husk fiber, $20 \%$ slash pine bark and needles, and $5.5 \mathrm{pH}$. The management practices adopted were similar to those used in commercial scale production by the providing company, with fertilization being done via irrigating water in the initial, growth and hardening off phases, and dosages being applied per cubic meter of substrate.

In the nursery, eight clones were assessed using a random block design with three replicates and four plants per plot, to a total of 96 seedlings, at age 120 days. In the field, a random block design was also used consisting of eight clones with four replicates and nine plants per plot, to a total of 288 plants arranged with $3 \times 2 \mathrm{~m}$ spacings, at age eight months.

Seedling height data were collected in the field, at age eight months. In the nursery, the following data were collected, at age 120 days: seedling height (Hm), root collar diameter (Dc), shoot diameter (Db). Shoot dry matter (PMSPA) and root dry matter (PMSR) were obtained in a laboratory. The following data were also obtained: total dry matter (PMST), ratio of shoot dry matter to root dry matter (PMSPA/PMSR), Dickson quality index of root collar diameter (IQD-Dc), Dickson quality index of shoot diameter (IQD-Db).

In order to measure seedling height in the field, a measuring tape marked in $\mathrm{cm}$ was used. For shoot height in the nursery, a ruler marked in cm was used. For measurements of root collar diameter and shoot diameter, a caliper marked in mm was used. The root portion of each seedling was then carefully washed, trying to keep all roots intact. The vegetal materials were crosscut at root collar level, separated into shoot and root portions, placed in labeled paper bags and taken to a forced air oven at $70^{\circ} \mathrm{C}$, to a constant weight. They were then weighed using an analytical scale accurate to $0.01 \mathrm{~g}$ to determine shoot dry matter (PMSPA) and root dry matter (PMSR).

The Dickson quality index of root collar diameter (IQD-Dc) and Dickson quality index of shoot diameter (IQD-Db) were calculated according to Dickson et al. (1960).

Nursery and field data were subjected to analysis of variance, following procedures described in program GENES (CRUZ, 2001). The statistical model of choice was:

$$
Y_{i j}=\mu+g_{i}+b_{j}+\varepsilon_{j i}
$$

where: $Y_{i j}$ is the mean value observed in the $i^{\text {th }}$ clone of the $\mathrm{j}^{\text {th }}$ block; $\mu$ is the grand mean; $\mathrm{g}_{\mathrm{i}}$ is the effect of the $\mathrm{i}^{\text {th }}$ clone (fixed effect); $b_{j}$ is the effect of the $j^{\text {th }}$ block (random effect); $\varepsilon_{\mathrm{ji}}$ is the experimental error.

The analysis of variance summary and expected mean square values for phenotypic, genotypic and environmental parameters are provided in Table 1.

Estimates of variance components, values of coefficient of genotypic determination $\left(\mathrm{h}^{2}\right)$ and coefficient of variation were obtained according to expressions described by Cruz and Carneiro (2003). Gains were predicted by selecting one clone in four being assessed ( $25 \%$ selection), normalizing selection intensity at 1.400 (COTTERILL; DEAN, 1990). 
Table 1 - Analysis of variance summary and expected mean square values, for phenotypic, genotypic and environmental parameters.

Tabela 1 - Esquema da análise de variância e estimativa das esperanças dos quadrados médios, para os parâmetros fenotípicos, genotípicos e ambientais.

\begin{tabular}{lcccc}
\hline Source & $\begin{array}{c}\text { Degree of } \\
\text { Freedom }\end{array}$ & E.M.S. & M.S. & $\mathrm{F}$ \\
\hline Blocks & $(\mathrm{r}-1)$ & $\sigma^{2}+\mathrm{c}^{2}{ }_{\mathrm{b}}$ & $\mathrm{Q}_{1}$ & $\mathrm{Q}_{1} \div \mathrm{Q}_{3}$ \\
Clones & $(\mathrm{c}-1)$ & $\sigma^{2}+\mathrm{r}^{2}{ }_{\mathrm{c}}$ & $\mathrm{Q}_{2}$ & $\mathrm{Q}_{2} \div \mathrm{Q}_{3}$ \\
Error & $(\mathrm{c}-1)(\mathrm{r}-1)$ & $\sigma^{2}{ }_{\mathrm{e}}$ & $\mathrm{Q}_{3}$ & \\
\hline
\end{tabular}

$\sigma^{2}$ : residual variance; $\hat{\phi}^{2}$ : genotype quadratic component; $\hat{\sigma}_{\mathrm{b}}^{2}$ : variance between blocks; c: number of clones; r: number of blocks.

\section{RESULTS AND DISCUSSION}

From Table 2 data, a significant difference is observed between clones, by the $\mathrm{F}$ test $(\mathrm{P} \leq 0.01)$, for all growth traits. This indicates the possibility of clone selection for improvement of growth traits in the nursery, and height growth in the field after planting.

Mean values found for growth traits of seedlings are: $2.45 \mathrm{~m}(\mathrm{Hc}), 18.56 \mathrm{~cm}(\mathrm{Hm}), 2.46 \mathrm{~mm}(\mathrm{Dc}), 1.65 \mathrm{~mm}$ (Db), $0.87 \mathrm{mg}$ (PMSPA), 0.40mg (PMSR), $1.27 \mathrm{mg}$ (PMST), 2.19 (PMSPA/PMSR), 0.13 (IQD-Dc), 0.10 (IQD-Db). The experimental coefficient of variation $\left(\mathrm{CV}_{\mathrm{e}}\right)$ was relatively low, ranging from $5.3 \%(\mathrm{Hm})$ to $13.0 \%$ (PMSR). According to Gomes et al. (2002), these low $\mathrm{CV}_{\mathrm{e}}$ values indicate good experimental precision, particularly in terms of environmental control and data collection. The genetic coefficients of variation $\left(\mathrm{CV}_{\mathrm{g}}\right)$ ranged from $8.4 \%$ (Hm) to $31.8 \%$ (IQD-Db). Considering these genotypic and environmental coefficients of variation, data demonstrate that $\mathrm{CV}_{\mathrm{g}} / \mathrm{CV}_{\mathrm{e}}$ ratios are $1.16(\mathrm{Hc}), 1.59(\mathrm{Hm}), 2.24(\mathrm{Dc})$, 2.61 (Db), 2.55 (PMSPA), 2.13 (PMSR), 2.50 (PMST), 1.23 (PMSPA/PMSR), 2.43 (IQD-Dc), 3.04 (IQD-Db).

According to Vencovsky and Barriga (1992), selection success is guaranteed if the above ratio is 1.0 or more. Therefore, obtained results indicate the possibility of attaining success for all growth traits being assessed.

Table 2 - Analysis of variance and estimate of population parameters for growth and morphological traits of nursery seedlings and for height growth of young field plants, at age eight months, of E. urophylla clones.

Tabela 2 - Análise de variância e estimativa dos parâmetros populacionais para caracteres morfológicos e de crescimento de mudas no viveiro e de crescimento em altura de plantas jovens no campo, aos oito meses de idade, de clones de E. urophylla.

\begin{tabular}{|c|c|c|c|c|c|c|c|c|c|c|c|}
\hline \multirow[b]{2}{*}{ Source } & \multirow[b]{2}{*}{ DF } & \multicolumn{10}{|c|}{ Mean square } \\
\hline & & $\begin{array}{l}\mathrm{Hc} \\
(\mathrm{m})\end{array}$ & $\begin{array}{l}\mathrm{Hm} \\
(\mathrm{cm})\end{array}$ & $\begin{array}{c}\mathrm{Dc} \\
(\mathrm{mm})\end{array}$ & $\begin{array}{c}\mathrm{Db} \\
(\mathrm{mm})\end{array}$ & $\begin{array}{l}\text { PMSPA } \\
(\mathrm{mg})\end{array}$ & $\begin{array}{c}\text { PMSR } \\
(\mathrm{mg})\end{array}$ & $\begin{array}{l}\text { PMST } \\
(\mathrm{mg})\end{array}$ & $\begin{array}{l}\text { PMSPA/ } \\
\text { PMSR }\end{array}$ & IQD-Dc & IQD-Db \\
\hline Block & 2 & 0.0262 & 0.196 & 0.0509 & 0.00027 & 0.0025 & 0.0047 & 0.0139 & 0.0357 & 0.0004 & 0.0001 \\
\hline Clone & 7 & $0.272 * *$ & $8.275 * *$ & $0.435 * *$ & $0.215 * *$ & $0.159 * *$ & $0.039 * *$ & $0.347 * *$ & $0.182 * *$ & $0.006 * *$ & $0.003 * *$ \\
\hline Residual & 14 & 0.0543 & 0.9693 & 0.0271 & 0.0101 & 0.0078 & 0.0027 & 0.0175 & 0.033 & 0.0003 & 0.0001 \\
\hline Mean & & 2.45 & 18.56 & 2.46 & 1.65 & 0.87 & 0.40 & 1.27 & 2.19 & 0.13 & 0.10 \\
\hline \multicolumn{2}{|c|}{$\mathrm{CV}_{\mathrm{e}}(\%)$} & 9.5 & 5.3 & 6.7 & 6.1 & 10.2 & 13 & 10.4 & 8.3 & 12.5 & 10.5 \\
\hline \multicolumn{2}{|c|}{$\mathrm{CV}_{\mathrm{g}}(\%)$} & 11.0 & 8.4 & 15.0 & 15.8 & 25.9 & 27.7 & 26.1 & 10.2 & 30.4 & 31.8 \\
\hline \multicolumn{2}{|c|}{$\sigma_{f}^{2}$} & 0.09079 & 2.75834 & 0.14509 & 0.07188 & 0.0533 & 0.01332 & 0.1157 & 0.06078 & 0.00169 & 0.00096 \\
\hline \multicolumn{2}{|l|}{$\sigma_{\mathrm{e}}^{2}$} & 0.01811 & 0.32309 & 0.00904 & 0.00335 & 0.0026 & 0.00091 & 0.00584 & 0.01101 & 0.00009 & 0.00003 \\
\hline \multicolumn{2}{|l|}{$\hat{\phi}_{c}^{2}$} & 0.07268 & 2.43525 & 0.13605 & 0.06853 & 0.0507 & 0.0124 & 0.10986 & 0.04977 & 0.0016 & 0.00093 \\
\hline \multicolumn{2}{|c|}{$\mathrm{h}^{2}(\%)$} & 80.0 & 88.3 & 93.8 & 95.3 & 95.1 & 93.2 & 95.0 & 81.9 & 94.6 & 96.5 \\
\hline \multicolumn{2}{|c|}{$\mathrm{CV}_{\mathrm{g}} / \mathrm{CV}_{\mathrm{e}}$} & 1.16 & 1.59 & 2.24 & 2.61 & 2.55 & 2.13 & 2.50 & 1.23 & 2.43 & 3.04 \\
\hline
\end{tabular}

** $\mathrm{P} \leq 0.01$; Hc: height of field seedlings, after eight months, Hm: height of nursery seedlings; Dc: root collar diameter; Db: shoot diameter; PMSPA: shoot dry matter; PMSR: root dry matter; PMST: total dry matter; PMSPA/PMSR: ratio of shoot dry matter to root dry matter; IQD-Dc: Dickson quality index using root collar diameter; IQD-Db: Dickson quality index of shoot diameter; $\mathrm{CV}_{\mathrm{e}}$ : experimental coefficient of variation (error); $\mathrm{CV}_{\mathrm{g}}$ : genetic coefficient of variation; $\sigma_{\mathrm{f}}^{2}$ : phenotypic variation; $\sigma_{\mathrm{e}}^{2}$ : environmental variation, $\hat{\phi}_{c}^{2}$ : genotype quadratic component; $\mathrm{h}^{2}$ : coefficient of genotypic determination; $\mathrm{CV}_{\mathrm{g}} / \mathrm{CV}_{\mathrm{e}}$ : variation index. 
Considering the high estimates of coefficient of genotypic determination $\left(\mathrm{h}^{2}\right)$, with percentage values of 80.0 (Hc), 88.3 (Hm), 93.8 (Dc), 95.3 (Db), 95.1 (PMSPA), 93.2 (PMSR), 95.0 (PMST), 81.9 (PMSPA/PMSR), 94.6 (IQD-Dc) and 96.5 (IQD-Db), relatively high gains can be expected from selection of superior trees for said traits.

Table 3 provides predicted genetic gains to be attained in all growth traits from direct selection of nursery seedlings, as well as indirect gains in initial field growth, at eight months after planting.

In forest improvement programs, correlations are used to assist selection involving two traits simultaneously, in other words, selection in one may have reflections, positive or negative, on another. Where reflections are positive, gains are directly obtained in the selected trait and indirect gains are obtained in the correlated trait. However, in order for this to happen, it is necessary that the genotypic correlation $\left(\mathrm{r}_{\mathrm{g}}\right)$ among the relevant traits be relatively high.

From the above correlation, a genetic material may be obtained capable of simultaneously gathering various favorable attributes (CRUZ; REGAZZI, 2001). On the other hand, where a trait is negatively correlated to another, one should be cautious that selection in one trait does not cause undesirable changes in another.

Considering a selection intensity of one clone in four, that is, $25 \%$, the growth trait showing the smallest direct gain (GD\%) was nursery seedling height $(\mathrm{Hm})$, with a GD of $10.0 \%$. The highest estimate of expected GD (39.7\%) was found for the Dickson coefficient index using shoot diameter (IQD-Db).
As for estimates of expected indirect genetic gains GI (\%) in field height growth (Hc), the most efficient seedling growth trait, at age 120 days, was root collar diameter (Dc), with a GI of $10.6 \%$, revealing indirect selection efficiency (ESI) of $84.4 \%$ (Table 3). Other important growth traits included PMSPA/PMST and IQDDc, with ESI values of $71.0 \%$ and $65.0 \%$ respectively. These ESI values indicate that PMSPA/PMSR, IQD-Dc and Dc constitute the main growth traits indicative of seedling quality in this clonal population.

According to Falconer (1987), indirect selection constitutes an important strategy to improve low heritability traits and/or traits considered difficult to measure.

In this specific study, these higher ESI values occurred due to the fact that the heritability of initial height growth in the field showed a heritability value relatively lower than growth traits of most efficient seedlings and/or due to higher values of genotypic correlation. From Table 3 data it was noted that the highest genotypic correlation coefficient $\left(r_{g}=0.8\right)$ found was between $\mathrm{Hc}$ and Dc, followed by $r_{g}=0.7$ and $r g=0.6$ for PMSPA/PMSR and IQD-Dc respectively.

Considering the three most important traits only regarding indirect gains expected for initial growth of field seedlings, it was noted that two clones, namely ITA-063 and ITA-069, showed the greatest height values in the field eight months after planting, $2.8 \mathrm{~m}$ and $2.7 \mathrm{~m}$ respectively (Table 4). Table 4 data shows that these clones also showed the highest values of root collar diameter, $3.23 \mathrm{~mm}$ and $2.69 \mathrm{~mm}$ respectively.

Table 3 - Estimated direct gain (GD), genetic correlation $\left(\mathrm{r}_{\mathrm{g}}\right)$, estimated indirect gain (GI) and indirect selection efficiency (ESI) for growth traits of seedlings and height of young field plants, at age eight months, of E. urophylla clones.

Tabela 3 - Previsão de ganho direto (GD), correlação genética $\left(r_{g}\right)$, previsão de ganho indireto (GI) e eficiência de seleção indireta (ESI) para caracteres de crescimento de mudas e altura de plantas jovens no campo, aos oito meses de idade, de clones de E. urophylla.

\begin{tabular}{|c|c|c|c|c|c|c|c|c|c|}
\hline \multirow{2}{*}{$\begin{array}{l}\text { Initial } \\
\text { height in the } \\
\text { field }(\mathrm{Hc}) \\
\mathrm{GD}(\%) \\
12.5\end{array}$} & \multicolumn{9}{|c|}{ Seedling growth traits } \\
\hline & $\begin{array}{c}\text { Dc } \\
\text { GD(\%) } \\
18.4\end{array}$ & $\begin{array}{c}\mathrm{Db} \\
\mathrm{GD}(\%) \\
19.7\end{array}$ & $\begin{array}{c}\text { PMSPA } \\
\text { GD (\%) } \\
32.2\end{array}$ & $\begin{array}{c}\text { PMSR } \\
\text { GD (\%) } \\
33.0\end{array}$ & $\begin{array}{c}\text { PMST } \\
\text { GD (\%) } \\
32.3\end{array}$ & $\begin{array}{c}\text { PMSPA/ } \\
\text { PMSR } \\
\text { GD (\%) } \\
11.7\end{array}$ & $\begin{array}{c}\text { IQD-Dc } \\
\text { GD (\%) } \\
37.6\end{array}$ & $\begin{array}{c}\text { IQD-Db } \\
\text { GD (\%) } \\
39.7\end{array}$ & $\begin{array}{c}\mathrm{Hm} \\
\text { GD (\%) } \\
10.0\end{array}$ \\
\hline$r_{g}$ & 0.8 & 0.4 & 0.5 & 0.3 & 0.5 & 0.7 & 0.6 & 0.5 & 0.3 \\
\hline GI (\%) & 10.6 & 5.6 & 7.5 & 3.9 & 6.4 & 9.0 & 8.1 & 6.4 & 3.5 \\
\hline ESI (\%) & 84.4 & 44.7 & 59.7 & 31.5 & 51.2 & 71.9 & 65 & 51.3 & 28.1 \\
\hline
\end{tabular}

Dc: root collar diameter; Db: shoot diameter; PMSPA: shoot dry matter; PMSR: root dry matter; PMST: total dry matter; PMSPA/ PMSR: ratio of shoot dry matter to root dry matter; IQD-Dc: Dickson quality index using root collar diameter and IQD-Db: Dickson quality index of shoot diameter, Hm: height of nursery seedling.

Cerne, Lavras, v. 17, n. 2, p. 189-193, abr./jun. 2011 
Table 4 - Estimates of mean values for morphological traits of nursery seedlings and height growth of young field plants, at age eight months, of E. urophylla clones.

Tabela 4 - Estimativas de médias para caracteres morfológicos de mudas no viveiro e de crescimento em altura de plantas jovens no campo, aos oito meses de idade, de clones de E. urophylla.

\begin{tabular}{ccccccccccc}
\hline Clone & $\begin{array}{c}\mathrm{Hc} \\
(\mathrm{m})\end{array}$ & $\begin{array}{c}\mathrm{Hm} \\
(\mathrm{cm})\end{array}$ & $\begin{array}{c}\mathrm{Dc} \\
(\mathrm{mm})\end{array}$ & $\begin{array}{c}\text { Db } \\
(\mathrm{mm})\end{array}$ & $\begin{array}{c}\text { PMSPA } \\
(\mathrm{mg})\end{array}$ & $\begin{array}{c}\text { PMSR } \\
(\mathrm{mg})\end{array}$ & $\begin{array}{c}\text { PMST } \\
(\mathrm{mg})\end{array}$ & $\begin{array}{c}\text { PMSPA/ } \\
\text { PMSR }\end{array}$ & IQD-Dc & IQD-Db \\
\hline ITA 011 & 2.3 & 16.83 & 2 & 1.33 & 0.545 & 0.243 & 0.788 & 2.24 & 0.074 & 0.053 \\
ITA 018 & 2.5 & 19.08 & 2.43 & 1.63 & 1.13 & 0.475 & 1.604 & 2.39 & 0.156 & 0.114 \\
ITA 022 & 2.1 & 18.64 & 2.3 & 1.56 & 0.783 & 0.425 & 1.208 & 1.847 & 0.122 & 0.088 \\
ITA 062 & 2.7 & 16.84 & 2.32 & 1.62 & 0.772 & 0.319 & 1.092 & 2.423 & 0.112 & 0.085 \\
ITA 063 & 2.8 & 22.13 & 3.23 & 2.23 & 1.278 & 0.617 & 1.895 & 2.083 & 0.213 & 0.16 \\
ITA 068 & 2.0 & 18.63 & 2.16 & 1.73 & 0.764 & 0.389 & 1.153 & 1.967 & 0.109 & 0.091 \\
ITA 069 & 2.7 & 18.00 & 2.69 & 1.70 & 0.798 & 0.315 & 1.114 & 2.543 & 0.121 & 0.085 \\
ITA 090 & 2.6 & 18.34 & 2.58 & 1.43 & 0.876 & 0.437 & 1.313 & 2.033 & 0.144 & 0.089 \\
\hline
\end{tabular}

Hc: height of field seedling, after eight months; Hm: height of nursery seedling; Dc: root collar diameter; Db: shoot diameter; PMSPA: shoot dry matter; PMSR: root dry matter; PMST: total dry matter; PMSPA/PMSR: ratio of shoot dry matter to root dry matter; IQD-Dc: Dickson quality index using root collar diameter and IQD-Db: Dickson quality index of shoot diameter.

Considering other correlations, it was noted that PMSPA/PMSR traits of clone ITA-069 showed the highest value (2.543). For clone ITA-063 the same ratio was 2.083. For IQD-Dc, clone ITA-063 showed the highest value, 0.213 .

\section{CONCLUSIONS}

- Significant differences exist among clones, for all traits being studied.

- The genetic control of traits is relatively high.

- A high correlation was found between initial field height and root collar diameter (Dc), ratio of shoot dry matter to root dry matter (PMSPA/PMSR) and Dickson quality index of root collar diameter (IQD-Dc) of nursery seedlings.

\section{REFERENCES}

ABRAF. Anuário estatístico da ABRAF: ano base 2008. Brasília, 2009. 129 p.

COMPANHIA DE PESQUISA DE RECURSOS MINERAIS. Projeto cadastro de abastecimento por águas subterrâneas, Estados de Minas Gerais e Bahia: diagnóstico do município de Taiobeiras, MG. Belo Horizonte, 2004. 15 p.

COTTERIL, P. P.; DEAN, C. A. Successful tree breeding with index selection. [S.1.]: CSIRO, 1990. 80 p.

\section{CRUZ, C. D. Aplicativo computacional em genética e} estatística: programa Genes: versão Windows. Viçosa, MG: UFV, 2001. 648 p.

CRUZ, C. D.; CARNEIRO, P. C. S. Modelos biométricos aplicados ao melhoramento genético. Viçosa, MG: UFV, 2003. $585 \mathrm{p}$.

CRUZ, C. D.; REGAZZI, A. J. Modelos biométricos aplicados ao melhoramento genético. 2. ed. Viçosa, MG: UFV, 2001. $390 \mathrm{p}$.

DICKSON, A.; LEAF, A. L.; HOSNER, J. F. Quality appraisal of white spruce and white pine seedling stock in nurseries. Forestry Chronicle, Ontário, v. 36, n. 1, p. 10-13, Jan./Feb. 1960.

FALCONER, D. S. Introdução à genética quantitativa. Viçosa, MG: UFV, 1987. 279 p.

GOMES, J. M.; COUTO, L.; LEITE, H. G.; XAVIER, A.; GARCIA, S. L. R. Parâmetros morfológicos na avaliação de qualidade de mudas de Eucalyptus grandis. Revista Arvore, Viçosa, v. 26, n. 6, p. 655-664, nov./dez. 2002.

VENCOVSKY, R.; BARRIGA, P. Genética biométrica no fitomelhoramento. Ribeirão Preto: Sociedade Brasileira de Genética, 1992. 406 p.

Cerne, Lavras, v. 17, n. 2, p. 189-193, abr./jun. 2011 